\title{
Pengaruh Asam Askorbat terhadap Pertumbuhan Colletotrichum coccodes Penyebab Antraknosa pada Tanaman Cabai Merah
}

\author{
Fadhila Meilasari, Juni Safitri Muljowati, Aris Mumpuni \\ Fakultas Biologi Universitas Jenderal Soedirman \\ Jalan dr. Suparno 63 Purwokerto 53122 \\ Email: fadhilameilasari65@gmail.com
}

\begin{abstract}
Rekam Jejak Artikel:
Diterima : 14/09/2019

Disetujui : 17/06/2020
\end{abstract}

\begin{abstract}
Pathogen Colletotrichum coccodes is one of the pathogens that can infect chili plants and cause anthracnose disease, especially in the fruit and leaves. Plants with high ascorbic acid content have a higher resistance to pathogen attack. Resistant chili plants have higher ascorbic acid content compared to tolerant and vulnerable chili plants. The purpose of this study was to determine the ability to grow pathogens of $C$. coccodes on ascorbic acid medium and to determine the effect of inoculation of $C$. coccodes pathogens on ascorbic acid content in chili leaves. This study uses two tests, namely the in vitro test and the in planta test with the experimental method completely randomized design (CRD), in vitro test using A) Medium PDA given ascorbic acid; B) PDB medium was given ascorbic acid with the treatment of adding ascorbic acid as much as $0 \mathrm{mg}$. $\mathrm{L}^{-1}$ (control); $0,25 \mathrm{mg}$. L $\mathrm{L}^{-1} ; 0.50 \mathrm{mg} . \mathrm{L}^{-1} ; 0,75 \mathrm{mg} . \mathrm{L}^{-1}$; and $1 \mathrm{mg}$ $\mathrm{L}^{-1}$. The main parameters are colony diameter and mycelium dry weight. In planta test uses three varieties of chili (V1: hot chili red chili; V2 curly red chili; V3: big red chili), The main parameters are the intensity of the disease, and supporting parameters are the incubation period, ascorbic acid content in chili leaves, temperature, humidity and soil $\mathrm{pH}$. The results of in vitro tests show that the pathogen of $C$. coccodes has good growth ability on PDA and PDB medium with the addition of ascorbic acid. In the in planta test, inoculation of the pathogen of $C$. coccodes on the red chili leaves causes symptoms of leaf spot disease and increases the content of ascorbic acid in the red chili plants.
\end{abstract}

Keyword: Colletotrichum coccodes, Red Chili, Anthracnose, Ascorbic Acid.

\begin{abstract}
Abstrak
Patogen Colletotrichum coccodes merupakan salah satu patogen yang dapat menginfeksi tanaman cabai dan menyebabkan penyakit antraknosa terutama pada bagian buah dan daun. Tanaman dengan kandungan asam askorbat tinggi memiliki ketahanan yang lebih tinggi terhadap serangan patogen. Tanaman cabai yang tahan memiliki kandungan asam askorbat yang lebih tinggi dibandingkan dengan tanaman cabai toleran maupun rentan. Tujuan penelitian ini adalah mengetahui kemampuan tumbuh patogen $C$. coccodes pada medium yang diberi asam askorbat dan mengetahui pengaruh inokulasi patogen $C$. coccodes terhadap kandungan asam askorbat pada daun cabai. Penelitian ini menggunakan dua uji yaitu uji in vitro dan uji in planta dengan metode eksperimental Rancangan Acak Lengkap (RAL), Uji in vitro menggunakan A) Medium PDA diberi asam askorbat; B) Medium PDB diberi asam askorbat dengan perlakuan penambahan asam

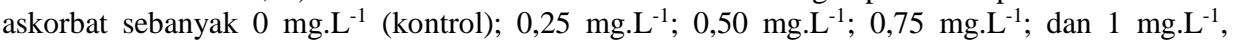
diulang sebanyak lima kali. Parameter utama yaitu diameter koloni dan bobot kering miselium. Uji in planta menggunakan tiga varietas cabai (V1: Cabai merah hot chili; V2 Cabai merah keriting; V3: Cabai merah besar). Parameter utama yaitu intensitas penyakit, dan parameter pendukung yaitu periode masa inkubasi, kandungan asam askorbat pada daun cabai, temperatur, kelembaban dan $\mathrm{pH}$ tanah. Hasil penelitian pada uji in vitro menujukkan bahwa patogen $C$. coccodes memiliki kemampuan tumbuh yang baik pada medium PDA dan medium PDB dengan penambahan asam askorbat. Hasil penelitian pada uji in planta, inokulasi patogen $C$. coccodes pada daun cabai merah dapat meningkatkan kandungan asam askorbat pada tanaman cabai merah Kata kunci : Colletotrichum coccodes, Cabai Merah, Antraknosa, Asam askorbat.
\end{abstract}

\section{PENDAHULUAN}

Tumbuhan memiliki respons fisiologis yang sangat bervariasi terhadap berbagai jenis tekanan lingkungan. Untuk mencegah kerusakan yang disebabkan oleh serangan patogen dan untuk adaptasi terhadap perubahan lingkungan, tanaman memiliki mekanisme baik secara langsung maupun tidak langsung untuk menanggapi rangsangan patogen. Asam askorbat diproduksi pada tanaman sebagai respon tidak langsung terhadap serangan patogen pada lokasi yang berbeda pada tumbuhan. Ekspresi terhadap respon ini dapat berupa rentan ataupun resisten terhadap patogen. Tanaman dengan kandungan asam askorbat tinggi memiliki ketahanan yang lebih tinggi terhadap serangan patogen (Khan et al., 2011). 
Asam askorbat terlibat dalam tanaman sebagai tanggapan terhadap tekanan biotik dan akan mengalami perubahan pada tanaman yang berinteraksi dengan patogen (Khan et al., 2011). Kandungan asam askorbat yang lebih tinggi dijumpai pada tanaman yang terserang patogen maupun pada tanaman yang tahan terhadap patogen. Tanaman yang tahan terhadap penyakit adalah tanaman yang mampu menghambat perkembangan patogen, sehingga patogen tidak dapat berkembang dan menyebar.

Ketahanan yang dimiliki oleh suatu tanaman terhadap patogen bervariasi. Varietas tahan adalah varietas dengan sifat-sifat yang memungkinkan tanaman itu pulih kembali dari serangan penyakit pada keadaan yang mengakibatkan kerusakan. Varietas rentan adalah varietas dengan sifat-sifat memungkinkan tanaman terinfeksi penyakit dan keparahan penyakit lebih besar (Palupi et al., 2015). Salah satu jenis tanaman yang memiliki banyak varietas adalah tanaman cabai merah. Setiap varietas mempunyai kemampuan tertentu untuk beradaptasi dengan lingkungan tempat tumbuhnya. Varietas cabai merah yang banyak dikonsumsi dan dibudidayakan oleh masyarakat antara lain varietas cabai merah keriting, cabai merah besar dan cabai merah hot chili (Ashari \& Andi, 2000)

Produktivitas cabai merah baik secara kualitas maupun kuantitas saat ini terhalang oleh berbagai hama dan penyakit. Penyakit utama yang sering ditemukan pada tanaman cabai merah di antaranya yaitu penyakit antraknosa yang disebabkan oleh patogen dari genus Colletotrichum. Colletotrichum merupakan genus besar yang terdiri dari sejumlah spesies penting dan merupakan patogen yang banyak menjadi penyebab beragam penyakit buah-buahan dan sayur-sayuran pada daerah tropis dan subtropis. Tanaman cabai merupakan salah satu tanaman yang rentan terhadap satu atau lebih spesies Colletotrichum (Dean et al., 2012). Colletotrichum mampu menginfeksi tanaman cabai pada bagian buah, daun dan ranting muda. Daun muda pada tanaman cabai lebih rentan terhadap antraknosa dibandingkan dengan daun tua. Daun - daun muda hanya rentan selama kurang lebih 5 hari pada waktu kuncup membuka, setelah itu daun membuka penuh, warnanya berubah menjadi hijau pucat. Kutikula daun kemudian terbentuk dan daun menjadi cukup tahan (Semangun, 2008).

Guna mengkaji peranan asam askorbat dalam hal ketahanan tanaman cabai merah terhadap patogen $C$. coccodes, maka perlu dilakukan pengujian kemampuan tumbuh $C$. coccodes dalam kaitannya dengan keberadaan asam askorbat baik secara secara in vitro maupun secara in planta. Berdasarkan uraian diatas maka muncul permasalahan bagaimana kemampuan tumbuh patogen $C$. coccodes pada medium yang diberi asam askorbat. Apakah pengaruh inokulasi patogen $C$. coccodes terhadap kandungan asam askorbat pada daun cabai merah.

Berdasarkan kenyataan tersebut penelitian ini bertujuan 1). mengetahui kemampuan tumbuh patogen $C$. coccodes pada medium yang diberi asam askorbat; 2). mengetahui pengaruh inokulasi patogen $C$. coccodes terhadap kandungan asam askorbat pada daun cabai merah.

Penelitian ini dapat memberi manfaat melalui kajian secara in vitro guna mengetahui kemampuan tumbuh patogen $C$. coccodes pada medium kultur dengan penambahan asam askorbat serta melalui kajian secara in planta guna mengetahui virulensi patogen $C$. coccodes yang dapat meningkatkan kandungan asam askorbat pada tanaman cabai merah.

\section{MATERI DAN METODE}

\section{Rancangan Penelitian}

Uji secara in vitro

Penelitian ini menggunakan metode eksperimental dengan Rancangan Acak Lengkap (RAL). Uji secara in vitro dilakukan dengan dua pengujian yaitu pada medium (1) Uji pada medium Potato Dextrose Agar (PDA), dan (2) Uji pada medium Potato Dextrose Broth (PDB). Kedua pengujian ini masing-masing menggunakan asam askorbat dengan_sesuai perlakuan yaitu $0 \mathrm{mg} . \mathrm{L}^{-1}$ (kontrol); 0,25 mg.L. ${ }^{-1} ; 0,50 \mathrm{mg} . \mathrm{L}^{-1}, 0,75 \mathrm{mg} . \mathrm{L}^{-1}$; dan $1 \mathrm{mg} . \mathrm{L}^{-1}$, diulang sebanyak lima kali.

\section{Uji secara in planta}

Penelitian ini menggunakan metode eksperimental dengan Rancangan Acak Lengkap (RAL). Uji secara in vivo dilakukan dengan dua pengujian yaitu (1) uji intensitas penyakit oleh $C$. coccodes, dan (2) uji kandungan asam askorbat pada daun tanaman cabai merah.

\section{Cara Kerja Penelitian}

Uji in vitro

1. Pembuatan medium PDA (Potato Dextrose Agar) (Dharmaputra et al., 1989)

Kentang dikupas dan ditimbang seberat 200 g, kemudian dicuci bersih dan dipotong dadu. Kentang tersebut direbus dengan $500 \mathrm{~mL}$ akuades dan dimasukkan dalam beaker glass volume $1000 \mathrm{~mL}$, direbus hingga kentang lunak. Air rebusan disaring dengan saringan dan hasil saringannya ditampung dalam beaker glass volume $1000 \mathrm{~mL}$. Sebanyak $20 \mathrm{~g}$ dextrose, $15 \mathrm{~g}$ agar, 1 g chloramphenicol dan ditambahkan 500 $\mathrm{mL}$ akuades sampai volume akhir $1000 \mathrm{~mL}$, kemudian dipanaskan menggunakan hotplate dan stirrer. Selanjutnya dituang ke dalam labu Erlenmeyer, kemudian disumbat menggunakan kapas dan disterilisasi menggunakan autoklaf pada temperatur $121^{\circ} \mathrm{C}$, tekanan 2 atm selama 15 menit. 
2. Peremajaan isolat jamur C. coccodes (Choi et al., 1999)

Biakan murni isolat $C$. coccodes diambil 1 plug dengan bor gabus berdiameter $8 \mathrm{~mm}$ dan diinokulasikan pada medium PDA kemudian diinkubasi pada temperatur ruang selama 7 hari.

3. Inokulasi $C$. coccodes pada medium PDA yang diberi Asam Askorbat (Mahiout et al., 2018)

Isolat $C$. coccodes diambil 1 plug dengan bor gabus berdiameter $8 \mathrm{~mm}$ dan diinokulasikan pada medium PDA yang diberi asam askorbat kemudian diinkubasi pada temperatur ruang selama 12 hari.

4. Pengukuran diameter koloni (Achmad et al., 2013)

Pengukuran diameter koloni C. coccodes dilakukan setiap hari selama 12 hari. Rumus untuk menghitung diameter koloni adalah :

$$
\mathrm{D}=\frac{\mathrm{d} 1+\mathrm{d} 2}{2}
$$

5. Pembuatan medium cair PDB (Potato Dextrose Broth) yang diberi asam askorbat (Achmad et al., 2013)

Pembuatan medium cair PDB sebanyak 2,5 L untuk 25 perlakuan dengan masing-masing perlakuan sebanyak $100 \mathrm{~mL}$. Pembuatan medium cair PDB diawali dengan mengupas kentang dan ditimbang seberat $500 \mathrm{~g}$, kemudian dicuci bersih dan dipotong dadu. Kentang tersebut direbus dengan akuades hingga lunak. Air rebusan disaring dengan saringan dan hasil saringannya ditampung dalam beaker glass. Dextrose sebanyak $50 \mathrm{~g}$, dan 2,5 g chloramphenicol dipanaskan dan ditambahkan air rebusan kentang yang telah disaring. Medium PDB diberi penambahan asam askorbat sesuai perlakuan. Medium dituang dalam labu erlenmeyer dengan volume $100 \mathrm{~mL}$ dan disterilisasi menggunakan autoklaf pada tekanan $1 \mathrm{~atm}$ dan temperatur $121^{\circ} \mathrm{C}$ selama 15 menit.

6. Inokulasi jamur $\mathrm{C}$. coccodes pada medium cair PDB yang diberi asam askorbat (Hanif et al., 2012)

Biakan C. coccodes diambil 3-5 plug dengan bor gabus berdiameter $8 \mathrm{~mm}$ dan diinokulasikan pada medium cair PDB yang diberi asam akorbat sesuai dengan perlakuan. Selanjutnya diinkubasi selama 14 hari pada temperatur ruang.

7. Pengukuran bobot kering biomassa miselium (Subowo, 2010)

Kultur yang telah diinkubasi selama 14 hari disaring dengan menggunakan kertas Whatman no.41. Miselium yang telah tersaring dioven pada temperatur $50-60^{\circ} \mathrm{C}$ selama 48 jam. Miselium yang telah kering kemudian ditimbang.
Uji in planta

1. Persiapan media tanam (Herwidyarti et al., 2013) Persiapan media tanam dilakukan dengan mencampurkan tanah dengan pupuk kandang kemudian di sterilisasi, selanjutnya dimasukkan ke dalam polybag dengan perbandingan 2:1.

2. Persemaian dan penanaman cabai merah (Marliah et al., 2011)

Benih cabai yang baik disemai pada baki berisi tanah steril hingga berumur 30 hari. Bibit kemudian dipindahkan ke media tanam polybag berisi 1 bibit tanaman. Tanaman cabai disiram dan dilakukan perawatan seperti penyiraman dan penyiangan.

3. Pengukuran $\mathrm{pH}$ tanah, Temperatur dan Kelembapan Greenhouse (Pitojo, 2003)

Pengukuran $\mathrm{pH}$ tanah pada media tanam menggunakan alat soil tester. Pengukuran $\mathrm{pH}$ tanah dilakukan sebelum penanaman tanaman cabai sebagai $\mathrm{pH}$ awal dan $\mathrm{pH}$ akhir diukur setelah tanaman diinokulasi patogen. Pengukuran temperatur dan kelembapan Greenhouse menggunakan termohygrometer. Pengukuran dilakukan setiap pagi dan sore setelah tanaman diinokulasi patogen.

4. Pembuatan inokulum jamur $C$. coccodes dan inokulasi (Nabila, 2015)

Pembuatan suspensi cair konidium dibuat menggunakan hasil peremajaan isolat jamur $C$. coccodes pada media miring yang berumur 7 hari setelah inkubasi. Suspensi konidium $C$. coccodes dengan kerapatan $5 \times 10^{5}$ konida/mL diinokulasi pada tanaman cabai saat tanaman cabai mulai tumbuh minimal 4-6 helai daun setelah tanam. Inokulasi dilakukan pada sore hari dengan cara disemprotkan pada permukaan daun pada bagian atas dan bawah dengan menggunakan sprayer. Pengamatan dilakukan dengan melihat gejala infeksi penyakit yang dapat diamati setiap minggu dimulai dari sehari setelah inokulasi sampai 2 minggu hingga muncul gejala.

5. Pengamatan Periode Masa Inkubasi (Purwantisari et al., 2016)

Masa inkubasi adalah waktu antara saat inokulasi patogen sampai timbulnya gejala awal penyakit. Setelah inokulasi jamur patogen, pengamatan dilakukan setiap hari untuk mengetahui kapan munculnya gejala penyakit antraknosa untuk pertama kali (waktu inkubasi).

6. Perhitungan Intensitas Penyakit (Rahardjo \& Suhardi, 2008)

Intensitas penyakit merupakan proporsi luas permukaan inang yang terinfeksi terhadap total luas permukaan inang yang diamati. Pengamatan intensitas penyakit dapat dihitung dengan rumus sebagai berikut:

$$
\mathrm{I}=\frac{\mathrm{z}(\mathrm{n} \times \mathrm{w})}{\mathrm{ZxN}} \times 100 \%
$$


7. Pengukuran Kandungan Asam Askorbat pada Daun Cabai (Badriyah \& Manggara, 2015) Pembuatan larutan induk Asam askorbat Asam askorbat ditimbang $50 \mathrm{mg}$, dimasukkan dalam labu seukuran $500 \mathrm{~mL}$ dan dilarutkan dalam akuades sampai tanda batas (sampai menunjukkan garis meniskus pada leher labu).

Penentuan panjang gelombang maksimum Asam askorbat

Larutan asam askorbat 100 ppm dipipet sebanyak $1 \mathrm{~mL}$ kedalam labu seukuran $50 \mathrm{~mL}$, lalu ditambahkan akuades sampai tanda batas (sampai menunjukkan garis meniskus pada leher labu) dan dihomogenkan. Diukur serapan maksimum pada panjang gelombang 200-400 nm dengan menggunakan blanko akuades.

\section{Pembuatan kurva kalibrasi asam askorbat}

Larutan Asam askorbat 100 ppm dipipet sebanyak $1 \mathrm{~mL}$ kedalam labu seukuran $50 \mathrm{~mL}$ masing - masing sebesar $2 \mathrm{ml}, 4 \mathrm{ml}, 6 \mathrm{ml}$, dan 8 $\mathrm{ml}$ (4 ppm, 8 ppm, $12 \mathrm{ppm}$, dan $16 \mathrm{ppm}$ ). Kemudian ditambahkan akuades hingga tanda batas (sampai menunjukkan garis meniskus pada leher labu) lalu dihomogenkan, kemudian diukur serapannya pada panjang gelombang maksimum yang diperoleh. Panjang gelombang maksimum yang digunakan adalah $260 \mathrm{~nm}$.

\section{Pengukuran kandungan Asam askorbat}

Daun cabai diambil bagian daun muda dan daun tua masing-masing sebanyak $1 \mathrm{~g}$, dibersihkan kemudian dihancurkan hingga halus menggunakan mortar dan pestle. Ditambah akuades sebanyak $10 \mathrm{~mL}$, kemudian disaring. Filtrat yang diperoleh dimasukkan dalam labu seukuran $100 \mathrm{~mL}$, ditambah akuades hingga tanda batas (sampai menunjukkan garis meniskus pada leher labu) kemudian dihomogenkan. Filtrat kemudian diukur serapan menggunakan spektrofotometer Ultraviolet visible (UV-Vis) pada panjang gelombang $260 \mathrm{~nm}$.

\section{Metode Analisis (Steel dan Torrie, 1995)}

Data uji in vitro dan uji in planta yang diperoleh dianalisis menggunakan analisis ragam (ANOVA) dengan tingkat kepercayaan $95 \%$, dan perlakuan yang memberikan perbedaan nyata dilanjutkan dengan Uji Beda Nyata Jujur (BNJ) pada tingkat kepercayaan $95 \%$.

\section{HASIL DAN PEMBAHASAN}

\section{Uji in vitro}

\section{Pengukuran diameter koloni Colletotrichum coccodes}

Berdasarkan hasil penelitan rata-rata pengukuran diameter koloni jamur Colletotrichum coccodes pada medium PDA (Tabel 1.)
Tabel 1. Hasil rata-rata diameter koloni $C$. coccodes pada medium PDA

\begin{tabular}{cc}
\hline Konsentrasi Asam & $\begin{array}{c}\text { Rata-rata diameter koloni } \\
\text { isolat C.coccodes }(\mathrm{mm})\end{array}$ \\
Askorbat $\left(\mathrm{mg} . \mathrm{L}^{-1}\right)$ & 83,45 \\
0 & 82,9 \\
0,25 & 64,96 \\
0,5 & 79,2 \\
0,75 & 82,75 \\
\hline
\end{tabular}

Berdasarkan Tabel 1. pertumbuhan koloni jamur $C$. coccodes paling baik yaitu pada medium PDA tanpa penambahan asam askorbat dengan ratarata pertumbuhan koloni 83,45 $\mathrm{mm}$ dan pertumbuhan koloni C.coccodes paling rendah yaitu pada konsentrasi asam askorbat $0,5 \mathrm{mg} . \mathrm{L}^{-1}$ dengan rata-rata pertumbuhan koloni dengan $64,96 \mathrm{~mm}$. Hasil ini menunjukkan bahwa pertumbuhah $C$. coccodes terhambat dengan adanya asam askorbat poada medium biakan. Hal ini sesuai dengan pernyataan Muljowati et al. (2018) bahwa medium dengan penambahan asam askorbat pada konsentrasi $0,5 \mathrm{mg} . \mathrm{L}^{-1}$ kurang sesuai untuk pertumbuhan jamur Colletotrichum.

Data rata-rata diameter koloni $C$. coccodes kemudian dianalisis dengan analisis ragam (ANOVA) pada tingkat kesalahan 5\%. Berdasarkan hasil ANOVA, penambahan asam askorbat pada medium PDA tidak berpengaruh nyata terhadap diameter koloni $C$. coccodes. Penambahan asam askorbat dalam media PDA memungkinkan $C$. coccodes tetap mampu tumbuh dan beradaptasi dengan lingkungannya.

\section{2. pengukuran bobot kering miselium $C$. coccodes}

Berdasarkan hasil penelitian pengukuran bobot kering miselium $C$. coccodes pada medium PDB tanpa penambahan asam askorbat dan dengan penambahan asam askorbat, jamur $C$. coccodes juga memiliki kemampuan tumbuh yang baik pada medium kultur PDB. Data bobot kering miselium $C$. coccodes selanjutnya dianalisis menggunakan analisis ragam (ANOVA) pada tingkat kesalahan 5\% (Lampiran 3.). Berdasarkan hasil ANOVA, penambahan asam askorbat pada medium PDB berpengaruh nyata terhadap pertambahan bobot kering miselium. Menurut Muljowati et al. (2018) jamur $C$. coccodes juga memiliki kemampuan tumbuh pada medium kultur PDB dengan penambahan asam askorbat sama hal nya seperti pada medium PDA dengan penambahan asam askorbat. Data bobot kering miselium $C$. coccodes diuji lanjut dengan uji BNJ pada tingkat kesalahan $5 \%$ (Tabel 2). 
Tabel 2. Hasil uji lanjut BNJ Pengaruh Pemberian Asam Askorbat Terhadap Bobot Kering Miselium C.coccodes

\begin{tabular}{cc}
\hline $\begin{array}{c}\text { Konsentrasi Asam } \\
\text { Askorbat } \\
\left(\mathrm{mg}^{-1}\right)\end{array}$ & $\begin{array}{c}\text { Rata-rata bobot kering } \\
\text { miselium C.coccodes }(\mathrm{mg})\end{array}$ \\
0 & $380^{\mathrm{a}}$ \\
0,25 & $244^{\mathrm{a}}$ \\
0,5 & $174^{\mathrm{b}}$ \\
0,75 & $234^{\mathrm{a}}$ \\
1 & $220^{\mathrm{a}}$ \\
\hline Keterangan: Angka dengan notasi yang berbeda menunjukkan \\
berbeda nyata dengan tingkat kesalahan 5\%
\end{tabular}

Berdasarkan hasil uji lanjut BNJ, pertumbuhan miselium C.coccodes pada medium kultur PDB pada perlakuan konsentrasi asam askorbat $0,5 \mathrm{mg} . \mathrm{L}^{-1}$ memiliki hasil yang berbeda nyata dengan keempat perlakuan lainnya yaitu pada konsentrasi asam askorbat $0 \mathrm{mg} . \mathrm{L}^{-1}, 0,25 \mathrm{mg} . \mathrm{L}^{-1}, 0,75$ dan $1 \mathrm{mg} . \mathrm{L}^{-1}$. Hal ini sejalan dengan pertumbuhan koloni jamur C.coccodes pada medium PDA yaitu medium dengan konsentrasi asam askorbat $0,5 \mathrm{mg} . \mathrm{L}^{-1} \mathrm{kurang}$ sesuai untuk pertumbuhan jamur Colletotrichum.

\section{Uji in planta}

\section{Perhitungan intensitas penyakit}

Perhitungan nilai kerusakan tanaman berdasarkan kategori yang diamati pada waktu pengamatan yang dilakukan pada akhir penelitian yaitu 14 hari setelah inokulasi C.coccodes. Data intensitas penyakit antraknosa pada daun cabai dianalisis menggunakan analisis ragam (ANOVA) pada tingkat kesalahan 5\%. Berdasarkan hasil ANOVA, perlakuan inokulasi C.coccodes pada daun cabai merah berpengaruh nyata terhadap intensitas penyakit antraknosa pada daun cabai.

Data hasil intensitas penyakit diuji lanjut dengan uji BNJ pada tingkat kesalahan 5\% (Tabel 3).

Tabel 3. Hasil uji lanjut BNJ Pengaruh Inokulasi C.coccodes Terhadap Intensitas Penyakit Pada Daun Cabai Merah

\begin{tabular}{cc}
\hline Perlakuan & Rata-rata Intensitas Penyakit (\%) \\
\hline V1P0 & $0,00^{\mathrm{a}}$ \\
V2P0 & $0,00^{\mathrm{a}}$ \\
V3P0 & $0,00^{\mathrm{a}}$ \\
V1P1 & $13,20^{\mathrm{c}}$ \\
V2P1 & $6,41^{\mathrm{b}}$ \\
V3P1 & $10,57^{\mathrm{c}}$ \\
\hline Keterangan: Angka dengan notasi yang berbeda menunjukkan \\
berbeda nyata dengan tingkat kesalahan 5\% \\
V1P0 = Varietas cabai merah hot chili tidak diinokulasi patogen \\
V2P0=Varietas cabai merah keriting tidak diinokulasi patogen \\
V3P0=Varietas cabai merah besar tidak diinokulasi patogen \\
V1P1= Varietas cabai merah hot chili diinokulasi patogen \\
V2P1=Varietas cabai merah keriting diinokulasi patogen \\
. V3P1=Varietas cabai merah besar diinokulasi patogen
\end{tabular}

Berdasarkan hasil uji lanjut $\mathrm{BNJ}$, pengaruh inokulasi patogen $C$. coccodes terhadap intensitas penyakit pada daun cabai merah diketahui pada perlakuan V1P0, V2P0, V3P0 tidak menunjukkan perbedaan dikarenakan tidak adanya perlakuan inokulasi patogen. Perlakuan V2P1 menunjukkan hasil yang berbeda nyata dari perlakuan V1P1 dan V3P1. Hal ini disebabkan tanaman cabai varietas cabai merah keriting memiliki kriteria ketahanan 'agak tahan', sedangkan varietas cabai merah besar dan varietas hot chili memiliki kriteria ketahanan 'agak rentan' berdasarkan skor dan kriteria ketahanan cabai merah terhadap penyakit antraknosa (Lampiran 6.). Menurut Agrios (1997) ketahanan terhadap penyakit dapat dikelompokkan ke dalam ketahanan struktural dan ketahanan fungsional. Contoh ketahanan struktural antara lain tebal tipisnya epidermis, adanya lignin pada dinding sel, adanya lapisan lilin pada permukaan daun. Ketahanan fungsional antara lain meningkatnya aktivitas enzim tertentu atau terbentuknya ketahanan zat toksik tertentu seperti fitoaleksin yang dapat mematikan patogen. Kombinasi antara sifat struktural dan reaksi biokimia yang digunakan untuk pertahanan bagi tanaman berbeda antara setiap sistem kombinasi inang-patogen, bahkan pada inang yang sama, kombinasi tersebut dapat berbeda dengan berbedanya jenis organ dan jaringan tanaman yang diserang, keadaan hara tanaman dan kondisi cuaca.

\section{Pengukuran kandungan Asam askorbat pada daun cabai}

Hasil pengukuran kandungan asam askorbat daun cabai merah menggunakan sampel daun muda an daun tua dari ketiga varietas tanaman cabai di sajikan pada Gambar 1.

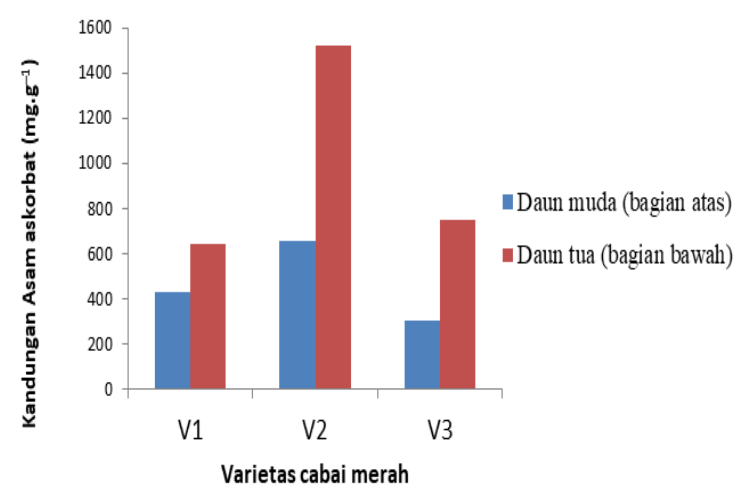

Gambar 1. Diagram rata-rata kandungan asam askorbat pada daun cabai merah

Keterangan:

$\mathrm{V} 1$ = Varietas cabai merah hot chili

$\mathrm{V} 2=$ Varietas cabai merah keriting

$\mathrm{V} 3=$ Varietas cabai merah besar

Berdasarkan Gambar 1. dapat dilihat asam askorbat pada daun tua (daun bagian bawah) tanaman cabai merah lebih tinggi dari daun muda (daun bagian atas). Hal ini dikarenakan inokulasi $C$. coccodes pada daun tua dilakukan lebih awal saat daun muda tanaman cabai merah belum muncul 
selama periode masa inkubasi. Data kandungan asam askorbat kemudian dianalisis dengan analisis ragam (ANOVA) pada tingkat kesalahan 5\% (Lampiran 5). Berdasarkan hasil ANOVA, inokulasi C. coccodes pada daun tanaman cabai merah berpengaruh nyata terhadap kandungan asam askorbat. Hal ini sesuai dengan pernyataan Boubakri (2017) bahwa kandungan asam askorbat akan meningkat seiring dengan terinfeksinya tanaman. Data kandungan asam askorbat pada daun cabai merah kemudian diuji lanjut dengan uji BNJ pada tingkat kesalahan 5\% (Tabel 4).

Tabel 4. Uji BNJ pada tingkat kesalahan 5\%

\begin{tabular}{cc}
\hline Perlakuan & $\begin{array}{c}\text { Rata-rata Kandungan } \\
\text { Asam askorbat }\left(\mathrm{mg}^{-1} \mathrm{~g}^{-1}\right)\end{array}$ \\
\hline V1P1 & $42,589^{\mathrm{a}}$ \\
V2P1 & $65,697^{\mathrm{b}}$ \\
V3P1 & $30,522^{\mathrm{a}}$ \\
V1P2 & $64,223^{\mathrm{a}}$ \\
V2P2 & $152,049^{\mathrm{b}}$ \\
V3P2 & $74,582^{\mathrm{a}}$ \\
\hline
\end{tabular}

Keterangan: Angka dengan notasi yang berbeda menunjukkan Keterangan: berbeda nyata dengan tingkat kesalahan $5 \%$

1. V1P1 =Daun muda (daun bagian atas) cabai merah hot chili

2. V2P1= Daun muda (daun bagian atas) cabai merah keriting

3. V3P1= Daun muda (daun bagian atas) cabai merah besar

4. $\mathrm{V} 1 \mathrm{P} 2=$ Daun tua (daun bagian bawah) cabai merah hot chili

5. V2P2= Daun tua (daun bagian bawah) cabai merah keriting

6. V3P2= Daun tua (daun bagian bawah) cabai merah besar

Berdasarkan hasil uji lanjut BNJ, pengaruh inokulasi patogen $C$. coccodes terhadap kandungan asam askorbat pada daun muda cabai merah keriting (V2P1) berbeda nyata dengan daun muda cabai merah hot chili (V1P1) dan pada daun muda cabai merah besar (V3P1). Kandungan asam askorbat pada daun tua cabai merah keriting (V2P2) juga menunjukkan hasil yang berbeda nyata dengan daun tua cabai merah hot chili (V1P2) dan daun tua cabai merah besar (V3P2). Kemampuan tanaman cabai merah varietas cabai merah keriting memproduksi asam askorbat lebih banyak sesuai dengan pernyataan Om \& Khirbat (2011) bahwa varietas tanaman yang tahan terhadap penyakit antraknosa memiliki kandungan asam askorbat lebih banyak dan gula lebih sedikit.

Kemampuan tumbuh dengan baik isolat $C$. coccodes pada medium kultur PDA maupun PDB dengan penambahan asam askorbat menunjukkan bahwa isolat $C$. coccodes memiliki virulensi yang tinggi dan dapat menginvasi dengan baik jika diinokulasi pada tanaman cabai merah. Varietas cabai merah keriting memiliki ketahanan yang lebih tinggi terhadap patogen $C$. coccodes dibuktikan dengan meningkatnya kandungan asam askorbat sebagai mekanisme pertahanan terhadap serangan patogen. Hal ini sesuai dengan pernyataan Muljowati et al. (2018) bahwa adanya infeksi patogen pada tumbuhan, maka tumbuhan akan memberikan respon pertahanan dengan memproduksi asam askorbat berlebih, dibandingkan pada kondisi normal.

\section{SIMPULAN}

Berdasarkan pembahasan tersebut di atas disimpulkan bahwa patogen C. coccodes dapat tumbuh dengan baik pada medium kultur PDA dan medium kultur PDB dengan penambahan asam askorbat. Inokulasi patogen C. coccodes dapat meningkatkan kandungan asam askorbat yang terdapat pada daun cabai merah.

\section{DAFTAR REFERENSI}

Achmad, Herliana, E.N. \& Octaviani, E.A. 2013. Pengaruh $\mathrm{pH}$, Penggoyangan Media dan Penamahan Serbuk Gergaji Terhadap Pertumbuhan Jamur Xylaria sp. Jurnal Silvikultur Tropika, 4(2), pp. 57-61.

Agrios, G. N. 1997. Ilmu Penyakit Tumbuhan. Edisi ke tiga, Yogyakarta: Gadjah Mada University Press.

Arrigoni, O., L, D.G., F, T. \& R, L. 1992. Changes in the ascorbate system during seed development of Vicia faba L. Plant Physiology. pp. 235-238.

Ashari, S. \& Andi, S., 2000. Pertumbuhan dan Hasil Dua Varietas Mentimun (Cucumis sativus L.). Jurnal ilmu-ilmu hayati. Universitas Brawijaya Malang.

Awadalla, O.A. 2008. Induction of Systemic Acquired Resistance In Tomato Plants Against Early Blight Disease. J. Exp. Biol. (Bot.), 4, pp. $53-59$.

Badriyah, L., \& Manggara, A.B. 2015. Penetapan kadar vitamin $\mathrm{C}$ pada cabai merah (Capsicum annuиm L.) menggunakan spektrofotometri UV-Vis. Jurnal Wiyata, 2 (1), pp. 25-28.

Boubakri, H. 2017. The Role of Ascorbic Acid in Plant-Pathogen Interactions. In Ascorbic Acid in Plant Growth, Development and Stress Tolerance. Springer International Publishing AG. pp.255-71.

Choi, Y.W., Hyde , K.D. \& Ho, W.H. 1999. Single spore isolation of fungi. Journal Fungal Divers , 3, pp. 29-38.

Dean, R., Van Kan, J.A.L., Pretorius, Z.A., Hammond-Kosack, K.E., Di Pietro, A. 2012. The Top 10 fungal pathogens in molecular plant pathology. Mol. Plant Pathol, 13, pp. 414-430.

Dharmaputra, O,S., Agustin, W.G, \& Napiah. 1989. Mikologi Dasar. Bogor: Departemen Pendidikan dan Kebudayaan Direktorat Jenderal Pendidikan Tinggi Pusat Antar Universitas Ilmu Hayati Institut Pertanian Bogor. 
Hanif, A., Suryanto, D. \& Nurwahyuni, I. 2012. Pemanfaatan Bakteri Kitinolitik dalam Menghambat Pertumbuhan Curvularia sp. Penyebab Penyakit Bercak Daun Pada Tanaman Mentimun. Jurnal Saintia Biologi, 1, pp. 33-39.

Herwidyarti, K.H., Ratih , S. \& Sembodo Dad, R.J. 2013. Keparahan Penyakit Antraknosa pada Cabai (Capsicum annuum L) dan Berbagai Jenis Gulma. Jurnal Agrotek Tropika, 1(1), pp. 102-106.

Khan, T.A., Mazid, M. \& Mohammad, F. 2011. Role of Ascorbic Acid Against pathogenesis in Plants. Journal of Stress Physiology \& Biochemistry, 7 (3), pp. 222-234

Mahiout, D., Bendahmane, B.S., Benkada, M.Y. Mekouar, H., Berrahal, N., \& Rickauer, M. 2018. First Report of Colletotrichum gloeosporioides on citrus in Algeria. Phytopathologia Mediterannea, 57(2), pp. 355-359.

Marliah, A., Nasution, M. \& Armin. 2011. Pertumbuhan dan Hasil Beberapa Varietas Cabai Merah Pada Media Tumbuh Yang Berbeda. J Floratek, 6, pp.84-91.

Muljowati, J.S., Dwiputranto, U., \& Chasanah, T. 2018. Pengaruh Asam Askorbat Terhadap Pertumbuhan Colletotrichum acutatum simmonds. Prosiding Seminar Nasional dan Call for Papers "Pengembangan Sumber Daya Perdesaan dan Kearifan Lokal Berkelanjutan VIII. pp. 76-84.
Nabila, R.Y. 2015. Perkembangan Cendawan Helminthosporium sp. dan Curvularia sp. pada Tanaman Gandum (Triticum aestivum L.). Skripsi. Bogor: Institut Pertanian Bogor.

Om, P \& S.K. Khirbat. 2011. Biochemichal basis of resistance to fruit rot (Colletotrichum capsici) in chilli genotype. Plant Disease Research, 26(2), p.180.

Palupi, H., Yulianah, I. \& Respatijarti. 2015. Uji Ketahanan 14 Galur Cabai Besar (Capsicum annuum L.) terhadap Penyakit Antraknosa (Colletotrichum spp) dan Bakteri (Ralstonia solanacearum). Jurnal Produksi Tanaman, 3(8), pp. 640-648.

Pitojo, S. 2003. Benih Kedelai. Yogyakarta: Kanisius.

Purwantisari, S., Priyatmojo, A., Sancayaningsih, R.P., \& Kasiamdari, R.S. Masa inkubasi gejala penyakit hawar daun tanaman kentang yang diinduksi ketahanannya oleh jamur antagonis Trichoderma viride. Bioma, 18 (1), pp. 41-47.

Rahardjo, I.B \& Suhardi. 2008. Insidensi dan Intensitas Serangan Penyakit Karat Putih Pada Beberapa Klon Krisan. J. Hort. 18(3), pp. 312-318.

Steel, R.G.D \& J.H. Torrie. 1995. Prinsip dan Prosedur Statistika: Suatu Pendekatan Biometrik. Penerjemah: Sumantri, B. Jakarta: Gramedia Pustaka Utama.

Subowo, Y.B. 2010. Uji Aktifitas Enzim Selulase dan Ligninase Dari Beberapa Jamur dan Potensinya Sebagai Pendukung Pertumbuhan Tanaman Terong (Solarium melongena). Berita biologi. 10 (1), pp. 1-6. 